\title{
Okra Infusion Water Improving Stress Oxidative and Inflammatory Markers on Hyperglycemic Rats \\ Tyagita $N^{1}$, Utami KP' $P^{2}$ Zulkarnain $\mathrm{FH}^{2}$, Rossandini $S M^{2}$, Pertiwi $N P^{2}$, Rifki $M A^{2}$, Safitri $A H^{1}$
}

\begin{abstract}
:
Objective: Okra has been known for its properties in improving diabetes markers. Most study used okra extract instead of its infusion water. Okra infusion water (OIW) contains polysaccharide and viscous fiber that delay gastric emptying, and help controlling glucose and $\mathrm{HbA} 1 \mathrm{C}$ level. As the glucose low level, so does the inflammation and oxidative stress on hyperglycemic rats. This study aims to investigate the effect of OIW in improving glucose level, HbA1C, SOD and CRP levels. Materials and methods: Posttest only control group design was applied to this experimental study using 15 male wistar rats divided randomly into 3 groups: Control, Streptozotocine (STZ), Streptozotocine+okra (OKRA). STZ, and OKRA groups induced with $65 \mathrm{mg} / \mathrm{kg}$ BW Streptozotocine and $110 \mathrm{mg} / \mathrm{kg}$ BW Nicotinamide on day 8. After the desirable glucose level achieved, OKRA were given $3.6 \mathrm{ml} \mathrm{OIW}$ on day 12-28. Data were analyzed using ANOVA in each variable. Results: Fasting and Postprandial Glucose level of OKRA $(137,40 \pm 3,57 \mathrm{mg} / \mathrm{dL}$ and $154.58 \pm 2.71 \mathrm{mg} / \mathrm{dL}), \mathrm{STZ}(251,77 \pm 2,30 \mathrm{mg} / \mathrm{dL}$ and $270.18 \pm 3.03 \mathrm{mg} / \mathrm{dL})$; HbA1C level of OKRA (7.93 \pm 0.25$)$, STZ (21.29 \pm 0.65$)$; SOD level of OKRA (55.292 $\pm 3.77 \%)$, STZ (16.472 $\pm 5.298 \%)$; CRP level of OKRA $(1,540 \pm 0,059 \mathrm{mg} / \mathrm{dL})$, STZ $(2,230 \pm 0,093 \mathrm{mg} / \mathrm{dL})$.Conclusions: OIW able to improve glucose, HbA1C, SOD, and CRP level on hyperglycemic rats.
\end{abstract}

Keywords: okra infusion water, hyperglycemic, streptozotocine induced rats

Bangladesh Journal of Medical Science Vol. 18 No. 04 October'19. Page : 748-752 DOI: https://doi.org/10.3329/bjms.v18i4.42879

\section{Introduction}

Diabetes Mellitus is a degenerative disease that leads to vascular comorbidities like coronary artery disease, detrimental effect on physical and cognitive function, and also death. ${ }^{1}$ Type 2 Diabetes Mellitus (DM2) caused by deficiency on insulin production, and insulin resistance. ${ }^{2}$ Diabetes Mellitus marked by hyperglycemia, an elevated blood glucose level beyond normal range. ${ }^{3}$ Hyperglycemia resulted from imbalance condition between hepatic glucose production during fasting, glucose intake, and periphery tissues resistance on insulin action. ${ }^{1}$ Hyperglycemia activate protein kinase $\mathrm{C}$, polyol, and hexosamine pathways, produce advanced glycosylated end products, leads to mitochondrial dysfunction, endoplasmic reticulum stress, thus promote accumulation of reactive oxygen species, and induce oxidative stress. Hyperglycemia also increase pro-inflammatory expression causing apoptosis. ${ }^{4}$ Chronic hyperglycemia resulted in long term damage, including eyes, kidneys, nerves, heart, and blood vessels. ${ }^{5}$ Therefore, controlling hyperglycemia is mandatory in order to prevent further damage either by administration of oral hypoglycemic agent, or plant with hypoglycemic properties.

Okra (Abelmoschusesculentus) is a crop that widely

1. Tyagita N, Biochemistry Department, Medical Faculty of UNISSULA, Semarang, Indonesia.

2. Utami KP, Student of Medical Faculty of UNISSULA, Semarang, Indonesi.

3. Zulkarnain FH, Student of Medical Faculty of UNISSULA, Semarang, Indonesi.

4. Rossandini SM, Student of Medical Faculty of UNISSULA, Semarang, Indonesi.

5. Pertiwi NP, Student of Medical Faculty of UNISSULA, Semarang, Indonesi.

6. Rifki MA, Student of Medical Faculty of UNISSULA, Semarang, Indonesi.

7. Safitri AH, Biochemistry Department, Medical Faculty of UNISSULA, Semarang, Indonesia.

Correspondence to: Azizah Safitri, Biochemistry Department, Medical Faculty of UNISSULA, Semarang, Indonesia. address: Jalan Kaligawe Raya KM.4, Terboyo Kulon, Genuk, Semarang, Central Java, Indonesia, email: azizah.safitri@unissula.ac.id 
known and used from Malvaceae family. Okra is a multipurpose crop used for its pods, seeds, leaves, flowers, stems, and buds on fresh conditions as vegetables in salads, soups, stews. Ethnomedicine also used okra mucilage as plasma replacement, cholesterol binding and so on. ${ }^{6}$ Powder of peel and seed of Okra (Abelmoschusesculentus) has been studied for its properties in lowering blood glucose level on streptozotocine induced rats. ${ }^{7}$ Overnight okra infusion water able to reduce blood glucose on rats, ${ }^{8}$ but did not evaluate the effect of its administration on stress oxidative and inflammation markers, therefore this study is needed to fill in the gap.

\section{Materials and methods}

\section{Streptozotocinee and Nicotinamide Doses}

Nicotinamide (NA) $110 \mathrm{mg} / \mathrm{kg}$ body weight was injected intra peritoneal to prevent the occurrence of Diabetes Mellitus type 1. Fifteen minutes after NA injection, Streptozotocinee (STZ) $65 \mathrm{mg} / \mathrm{kg}$ body weight was then injected intra peritoneal. Leave for three days to achieve the desirable serum glucose level.

\section{Preparation of Okra Infusion Water}

Green colored okra with smooth and intact surface was purchased from traditional market. Three fresh okra's pod were sliced and infused in $250 \mathrm{ml}$ water. After 12 hours, okra pieces were removed, the already slimy water were then given to rats in OKRA group using oral gauge. Daily consumption of okra in human range 2-3 pods, weigh 20 grams, then infused in $200 \mathrm{ml}$ potable water. Thus, the conversion dose for rats is $3.6 \mathrm{ml} \mathrm{Okra}$ Infusion Water (OIW). The okra infusion water was freshly made every day, and given every morning, from day 8 until day 39.

\section{Study design and animals}

Posttest only controlled group design was applied to this experimental study. Using 15 male wistar rats, aged 3 months, weighed 200 grams, obtained and maintained in Centre for Food and Nutrition (Pusat Studi Pangandan Gizi) of Gajah Mada University, Yogyakarta Indonesia. After being acclimatized for 7 days using only standard pellet and distilled water ad libitum, rats were randomly divided into 3 groups as follow:

\begin{tabular}{ll} 
& \multicolumn{2}{l}{ Received only standard pellet } \\
and distilled water, without \\
CONTROL \\
group & $\begin{array}{l}\text { any streptozotocine and } \\
\text { Nicotinamide (STZ \& NA) } \\
\text { injection, or okra. }\end{array}$ \\
STZ group & $: \begin{array}{l}\text { Injected with STZ \& NA } \\
\text { Injected with STZ \& NA, given } \\
\text { OKRA group }\end{array}$ \\
& $3.6 \mathrm{ml}$ okra infusion water
\end{tabular}

On day 8, STZ, and OKRA group were injected with $110 \mathrm{mg} / \mathrm{kg}$ BW Nicotinamide and $65 \mathrm{mg} / \mathrm{kg}$ BW streptozotocine intraperitoneal, leave for 3 days with ad libitum diet and distilled water. On day 11 , blood glucose were then measured using glucometer. Hyperglycemia obtained if the glucose level $>200$ $\mathrm{mg} / \mathrm{dL}$ and followed by treatment in each group.

After the desirable glucose level was achieved, okra infusion water was given for 28 days in OKRA group. At the end of treatment (day 40), rats were fasted overnight. Blood samples were collected from rats using ophthalmic vein, measured for its glucose (fasting and postprandial), $\mathrm{HbA1C}, \mathrm{SOD}$, and CRP level.

\section{The Evaluation of Blood Glucose, HbA1C, SOD and CRP level}

Rats were fasted overnight. In the morning, blood serum was collected from ophthalmic vein, measured for fasting glucose level using enzymatic glucometer. Rats were then fed with standard pellet, fasted for 2 hours, and measured for post prandial glucose using the same method as the fasted glucose before. Blood collected were tested for $\mathrm{HbA1C}$, SOD, and CRP using ELISA.

\section{Statistical analysis}

Statistical analysis of this study were performed using SPSS 22. Both descriptive (mean, and standard deviation) and inferential test were used to analyze the results. ANOVA was used to compare differences within each variable, considered significance only if $\mathrm{p}<0.05$. Ethical clearance: This study was performed after being approved by Health/ Medical Research Bioethic Commission, Medical Faculty of UNISSULA (No. 289/IX/2017/Bioethic Commission).

\section{Results}

After being acclimatized, rats on STZ, and OKRA group were injected with STZ and NA on day 8 . Blood glucose level were analyzed at day 11 (Table 1) to evaluate whether the hyperglycemic induction was succeeded or not.

Table 1. Mean Blood Glucose Level $( \pm$ SD) after injected with STZ \& NA

\begin{tabular}{cccc}
\hline & STZ & OKRA & p \\
\hline $\begin{array}{c}\text { Blood Glucose } \\
\text { Level }\end{array}$ & $225.34 \pm 5.11$ & $221.28 \pm 4.78$ & 0.077
\end{tabular}

The induction was succeeded, blood glucose level was more than $200 \mathrm{mg} / \mathrm{dL}$, and all those three groups showed no differences $(p>0.05)$. The treatment for each groups were then conducted for 28 days. The glucose level (both fasting and postprandial glucose 
level), HbA1C, SOD, and CRP level at the end of treatment (day 40) were displayed at Table 2.

Table 2. Mean $( \pm \mathrm{SD})$ Fasting, postprandial glucose level, HbA1C, SOD, and CRP level after treatment (at day 40)

\begin{tabular}{ccccc}
\hline Variable & CONTROL & STZ & OKRA & p ANOVA \\
\hline $\begin{array}{c}\text { Fasting Glucose } \\
(\mathrm{mg} / \mathrm{dL})\end{array}$ & $83.68 \pm 0.46$ & $251.77 \pm 1.03$ & $137.4 \pm 3.57$ & 0.000 \\
$\begin{array}{c}\text { Postprandial } \\
\text { Glucose (mg/dL) }\end{array}$ & $98.48 \pm 3.09$ & $270.18 \pm 3.03$ & $154.58 \pm 2.71$ & 0.000 \\
HbAlC (\%) & $4.37 \pm 0.41$ & $21.29 \pm 0.65$ & $7.93 \pm 0.25$ & 0.000 \\
SOD (mg/dL) & $83.53 \pm 4.07$ & $16.47 \pm 5.3$ & $55.29 \pm 3.77$ & 0.000 \\
CRP (mg/dL) & $0.69 \pm 0.54$ & $2.23 \pm 0.09$ & $1.54 \pm 0.06$ & 0.000 \\
\hline
\end{tabular}

The best results for fasting \&postprandial glucose level, $\mathrm{HbA1C}$, SOD, and CRP level were found in CONTROL group (p 0.000), followed by OKRA group, and the worst results were on STZ group.

Posthoc test was conducted in order to evaluate the significant difference between groups. The differences between fasting, postprandial glucose, and $\mathrm{HbA1C}$ level was shown in figure 1, while the CRP and SOD level between groups was shown in figure 2 .

\section{Discussion}

Streptozotocine and Nicotinamide (STZ-NA) were succeed in diabetic/hyperglycemic induction in this study. Mean glucose level on STZ, and OKRA group after being induced with STZ-NA were significantly higher than in the CONTROL group, which was received no induction at all. Other study using 110 $\mathrm{mg} / \mathrm{kg}$ BW NA and $65 \mathrm{mg} / \mathrm{kg}$ BW STZ was also showed hyperglycemic condition, marked by blood glucose level $>200 \mathrm{mg} / \mathrm{dL}$. Streptozotocine known for its high affinity for $\beta$ cell membrane, generate free radical formation, which causes DNA methylation and breaks, activate poly ADP ribose polymerase (PARP$1)$, decreases $\mathrm{NAD}^{+}$, and leads to energy deprivation and $\beta$ cell death. Thus impairing insulin production and secretion. ${ }^{9}$ While STZ has a detrimental effect on $\beta$ cell, Nicotinamide protected it. Nicotinamide acts as an oxygen free radicals scavenger, inhibiting PARP-1, and increasing $\mathrm{NAD}^{+}$, thus $\mathrm{NA}$ is able to protect $\beta$ cell's damage from STZ induction, and modulate the occurrence of Diabetes Mellitus type. ${ }^{10}$ After successfully induced by STZ-NA, rats on OKRA group were treated with okra. The results for fasting and postprandial glucose level in OKRA group was better than those in STZ group. This results is similar to Sabitha's, administration of Okra's peel and seed powder decreased elevated blood glucose after STZ induction. ${ }^{7}$ Okra's extract also showed reduction in blood glucose of STZ
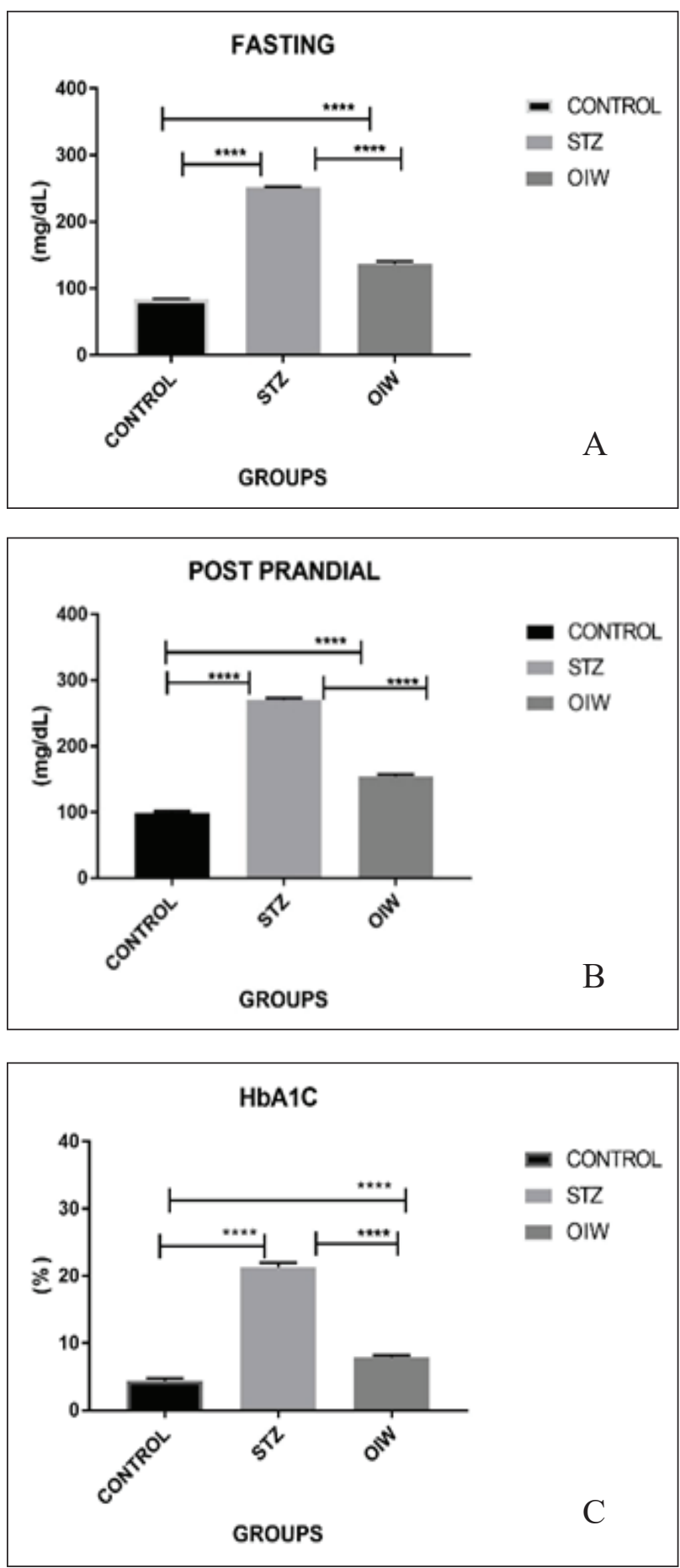

Figure 1. The fasting (A), postprandial glucose (B), and HbA1C (C) level between groups $(* * * * p<0.0001)$

induced diabetic mice. ${ }^{8}$ Okra infusion water contains viscous water soluble dietary fiber. ${ }^{6}$ Administration of viscous water soluble dietary fibers reduced glucose diffusion and postponing the absorption and carbohydrate digestion, therefore reducing postprandial blood. ${ }^{11}$ Fiber consumption associated with beneficial shifts in gut microbial composition. ${ }^{12}$ Dietary fibers resist digestion in intestine, therefore it is fermented to produce short chain fatty acid/ 

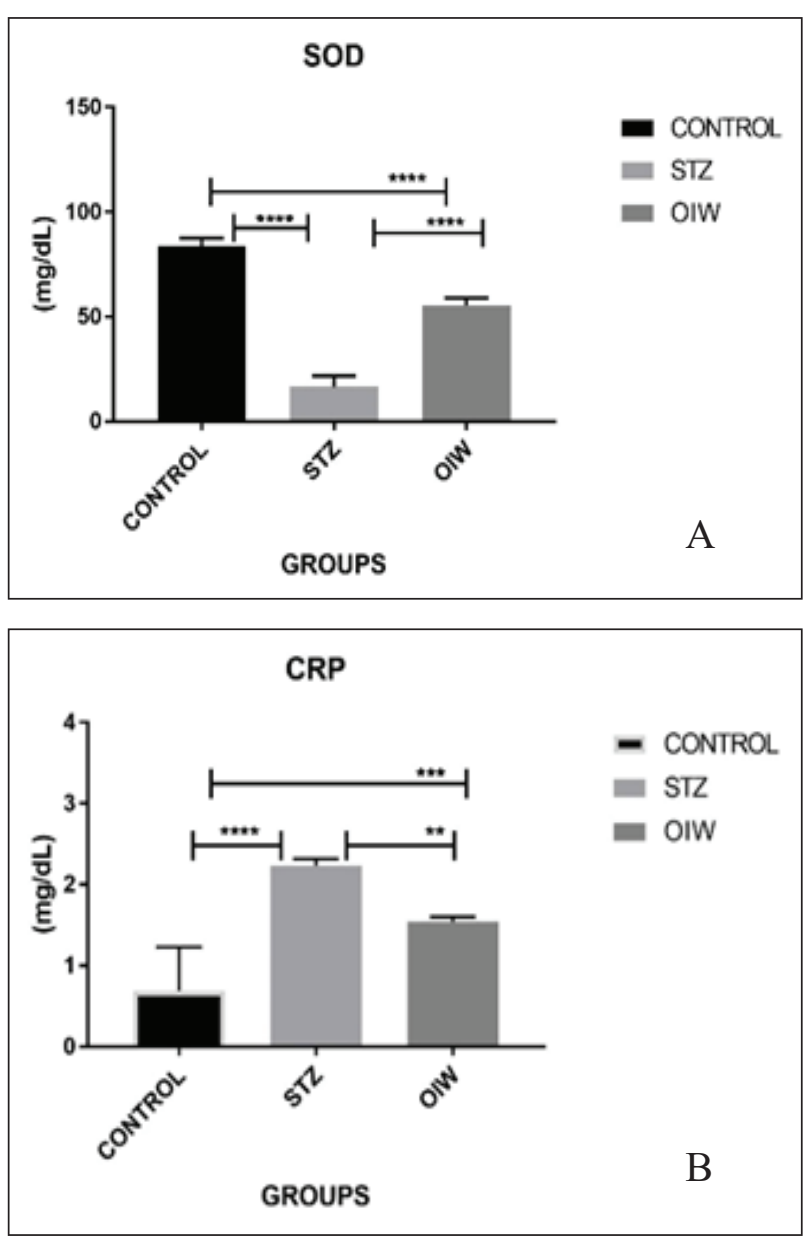

Figure 2. SOD (A) and CRP (B) level between groups $(* * * * \mathrm{p}<0.0001)$

SCFA. SCFA reducing serum free fatty acids, hence decrease blood glucose levels through competition in insulin-sensitive tissues. ${ }^{13}$ Isoquercetin and quercetin 3-O-gentibioside in okra has ability to inhibit carbohydrate metabolizing enzyme, maltase and sucrose, and act as $\alpha$-glucosidase inhibitors. ${ }^{14}$ Other study found that ethanol extract of Okra administration inhibited Peroxisome Proliferatoractivated receptor $\left(\mathrm{PPAR}_{Y}\right)$, the important regulator in glucose and lipid homeostasis. ${ }^{15}$

The present study also showed the HbA1C level in OKRA group was found lower than in STZ group. Study from Sabitha also found that Hba1C in the administration of Okra's peel and seed powder is lower than those in diabetic rats group. ${ }^{7} \mathrm{HbA} 1 \mathrm{C}$ is a modified form of hemoglobin, derived from nonenzymatic binding between glucose and hemoglobin via Amadori reaction. ${ }^{16}$ The $\alpha$-glucosidase inhibitorsproperty from okra reducing glucose level, ${ }^{14}$ minimizing the binding between glucose and hemoglobin, hence reducing the $\mathrm{HbA1C}$ score.

While the glucose parameter shown improvement with Okra's administration, the same pattern also seen in inflammation marker, C-reactive protein/CRP. Diabetes Mellitus associated with inflammation, marked by an increase in CRP level. ${ }^{17} \mathrm{CRP}$ in OKRA group was better than CRP level in STZ group. In a study on diabetic patients consuming more dietary fiber also shown a reduction in CRP level. ${ }^{18}$ Dietary fiber intake was shown to reduce circulating level of CRP. ${ }^{19,20}$ The possible mechanisms of this reduction is due to its ability to slow down the glucose absorption, regulate insulin sensitivity, and reduce lipid oxidation, hence alleviate inflammation process. ${ }^{21}$ High fiber diet also contains vitamins, minerals, and antioxidants which may reduce inflammation through other pathways. ${ }^{19}$ Myricetin in Okra is able to improve carbohydrate metabolism and enhance glucose utilization. ${ }^{21}$ Myricetin inhibit the production of pro-inflammatory mediators. Myricetin suppress NF- $\kappa$ B and STAT1 activation and Nrf2-mediated HO-1 expression pathways. NF- $\mathrm{kB}$ is a key for inflammatory mediators production. ${ }^{20}$

Okra contains polyphenols and flavonoids in its pod and seed. ${ }^{22}$ The SOD level on OKRA group was higher than SOD level on STZ group. This results is in-line with previous study, the administration of okra seed increase SOD level in mice. ${ }^{23}$ Okra's pod contains quercetin, myricetin, ascorbic acid. ${ }^{6}$ Quercetin is a potent antioxidant which act as an enhancer for endogenous antioxidant enzymes activity (such as SOD), and also act as an inhibitor for generation of free radical generation. ${ }^{24}$ Quercetin is able to increase tissue total antioxidant capacity, lowering tissue oxidant level and oxidative stress. ${ }^{25}$ Ascorbic acid interact with harmful free radical, quenching free radical until became less reactive, and thus increase SOD level. ${ }^{26}$ Myricetin, also act as an antioxidant if combined with ascorbic acid, by removing central atom of the iron-ascorbic acid complex, reducing oxidative stress, and increasing endogen antioxidant. ${ }^{27,28}$

\section{Conclusions}

Okra infusion water improve fasting glucose level, postprandial glucose level, HbA1C, CRP and SOD level of diabetic induced rats.

\section{Conflict of interest: None}

\section{Authors' contribution:}

Data gathering and idea owner of this study: Tyagita N, Study design: Tyagita N,

Data gathering: Tyagita N, Utami KP, Zulkarnain FH, Rossandini SM, Pertiwi NP, Rifki MA, Safitri AH.

Writing and submitting manuscript: Tyagita $\mathrm{N}$

Editing and approval of final draft: Tyagita N, Utami KP, Pertiwi NP, Rifki MA, Safitri AH 


\section{References:}

1. Lee, P. G. \& Halter, J. B. The Pathophysiology of Hyperglycemia in Older Adults: Clinical Considerations. Diabetes care40, 444-452 (2017).

2. Wang P, Fiaschi-Taeschi NM, Vasavada RC, Scott DK, Garcia-Ocana A, S. A. Diabetes mellitus - advances and challenges in human $\beta$-cell proliferation. Nature Reviews Endocrinology11, 201-212 (2015).

3. PERKENI. Konsensus Pengendalian dan Pencegahan Diabetes Melitus Tipe 2 di Indonesia 2015. Perkeni (2015). doi:10.1017/CBO9781107415324.004

4. Fiorentino, T. V., Prioletta, A., Zuo, P. \& Folli, F. Hyperglycemia-induced oxidative stress and its role in diabetes mellitus related cardiovascular diseases. Current pharmaceutical design19, 5695-703 (2013).

5. ADA. Diagnosis and Classification of Diabetes Mellitus. Diabetes Care37, S81-S90 (2014).

6. Gemede, H. F., Ratta, N., Haki, G. D. \& Woldegiorgis, A. Z. Nutritional Quality and Health Benefits of Okra ( Abelmoschus esculentus ): A Review. 33, 87-97 (2014).

7. Sabitha, V., Ramachandran, S., Naveen, K. R. \& Panneerselvam, K. Antidiabetic and antihyperlipidemic potential of Abelmoschus esculentus (L.) Moench. in streptozotocin-induced diabetic rats. Journal of Pharmacy and Bioallied Sciences3, 397-402 (2011).

8. Ray, J., Perez, T., Baritua, R. J., Pacalna, M. O. \& Malayao, S. O. Exploratory Investigation On The Hypoglycemic Effect Of Abelmoschus Esculentus In Mice. International Journal of Scientific \& Technology Research2, 249-253 (2013).

9. Ghasemi, A., Khalifi, S. \& Jedi, S. Streptozotocinnicotinamide-induced rat model of type 2 diabetes (review). Acta Physiologica Hungarica101, 408-420 (2014).

10. Kishore, L., Kajal, A. \& Kaur, N. Role of Nicotinamide in Streptozotocin Induced Diabetes in Animal Models. Mini Review J Endocrinol Thyroid Res2, (2017).

11. Yokoyama, W. H. et al. Effect of Barley $\beta$-Glucan in Durum Wheat Pasta on Human Glycemic Response. Cereal Chemistry Journal74, 293-296 (1997).

12. Cani, P. D. et al. Gut microbiota fermentation of prebiotics increases satietogenic and incretin gut peptide production with consequences for appetite sensation and glucose response after a meal. The American Journal of Clinical Nutrition90, 1236-1243 (2009).

13. Lattimer, J. M. \& Haub, M. D. Effects of dietary fiber and its components on metabolic health. Nutrients2, 12661289 (2010).

14. Thanakosai, W. \& Phuwapraisirisan, P. First identification of $\alpha$-glucosidase inhibitors from okra (Abelmoschus esculentus) seeds. Natural product communications8, 1085-8 (2013).

15. Fan, S. et al. Okra polysaccharide improves metabolic disorders in high-fat diet-induced obese C57BL/6 mice. Molecular Nutrition \& Food Research57, 2075-2078 (2013).

16. Leow, M. K. S. Glycated Hemoglobin (HbA1c): Clinical Applications of a Mathematical Concept. Acta informatica medica: AIM : journal of the Society for Medical Informatics of Bosnia \& Herzegovina : casopis Drustva za medicinsku informatiku BiH24, 233-238
(2016)

17. Lottenberg, A. M. P., Fan, P. L. T. \& Buonacorso, V. Effects of dietary fiber intake on inflammation in chronic diseases. Einstein (Sao Paulo, Brazil)8, 254-8 (2010).

18. Begum, I.A.; Sen, M.; Afrin, S.F.; Moutoshi S.S.; Islam, M.A; Rahman, M. H. Association of dietary fiber with high sensitivity $\mathrm{C}$-reactive proteinin type 2 diabetes mellitus. Bangladesh Journal of Medical Science11, 5155 (2012).

19. Villaseñor, A. et al. Dietary fiber is associated with circulating concentrations of C-reactive protein in breast cancer survivors: the HEAL study. Breast Cancer Res Treat129, 485-494 (2011).

20. Cho, B. O. et al. Anti-inflammatory activity of myricetin from diospyros lotus through suppression of $\mathrm{nf}-\mathrm{kb}$ and stat1 activation and nrf2-mediated ho-1 induction in lipopolysaccharide-stimulated raw264.7 macrophages. Bioscience, Biotechnology and Biochemistry80, 1520 1530 (2016).

21. Kandasamy, N. \& Ashokkumar, N. Protective effect of bioflavonoid myricetin enhances carbohydrate metabolic enzymes and insulin signaling molecules in streptozotocin-cadmium induced diabetic nephrotoxic rats. Toxicology and Applied Pharmacology279, 173-185 (2014).

22. Prabhune, A., Sharma, M., Ojha, B. \& Prabhune, C. A. Abelmoschus esculentus (Okra) potential natural compound for prevention and management of Diabetes and diabetic induced hyperglycemia: Review. International Journal of Herbal Medicine IJHM5, 65-68 (2017).

23. Xia, F. et al. Antioxidant and Anti-Fatigue Constituents of Okra. Fax, 86-10

24. Dong, Y. et al. Protective effect of quercetin against oxidative stress and brain edema in an experimental rat model of subarachnoid hemorrhage. International journal of medical sciences11, 282-90 (2014).

25. Ertuğ, P. U., Aydinoglu, F., Goruroglu Ozturk, O., Singirik, E. \& Ögülener, N. Comparative study of the quercetin, ascorbic acid, glutathione and superoxide dismutase for nitric oxide protecting effects in mouse gastric fundus. European Journal of Pharmacology698, 379-387 (2013).

26. Lu, X. L., Song, Y. H., Fu, Y. B., Si, J. M. \& Qian, K. Da. Ascorbic acid alleviates pancreatic damage induced by dibutyltin dichloride (DBTC) in rats. Yonsei Medical Journal48, 1028-1034 (2007).

27. Demikhova, N., Chernatska, O., Mazur, T., Bokova, S., Rudenko, T., Bumeister, L., \& Demikhov, O. (2018). Markers of cardiovascular complications in patients with type 2 diabetes mellitus and arterial hypertension. Bangladesh Journal of Medical Science, 17(2), 319-322. https://doi.org/10.3329/bjms.v17i2.35894

28. Chobot, V. \& Hadacek, F. Exploration of pro-oxidant and antioxidant activities of the flavonoid myricetin. Redox Report16, 242-247 (2011). 